\title{
DAMPAK CORPORATE GOVERNANCE TERHADAP KONSERVATISMA AKUNTANSI DI PERUSAHAAN YANG LISTING PADA JAKARTA ISLAMIC IDEXS
}

\author{
Febri Rahmi, SE. M.Sc. Ak.
}

\begin{abstract}
Abstrak
Penerapan corporate governance merupakan salah satu faktor yang mampu membangun dan mewujudkan pasar modal yang sehat. Perusahaan yang telah menerapkan corporate governance yang baik akan mendapat penghargaan pada nilai saham atau premium sebesar $20 \%$ - 30\%. Negara yang memiliki pasar modal yang besar akan memiliki pertumbuhan ekonomi yang lebih cepat di masa dating
\end{abstract}

Kata Kunci : corporate governance, pasar modal, pertumbuhan ekonomi

\section{PENDAhUluan}

\subsection{Latar Belakang}

Keberhasilan perusahaan sebelum adanya Corporate Governance hanya dilihat dari hasil laporan keuangan (financial statement). Laporan keuangan yang dibuat oleh pihak manajemen perusahaan dapat digunakan oleh berbagai pihak yang membutuhkan baik intern (pemilik, pegawai ) dan ekstern (investor dan pemerintah), namun terkadang informasi yang diberikan tidak menunjukan realita yang sebenarnya tergantung kegunaan informasi keuangan tersebut. Seperti untuk kepentingan investor, pihak manajemen perusahaan berusaha menyajikan laba tinggi pada laporan keuangan. Sementara itu untuk kepentingan pajak, informasi laba yang disajikan dibuat rendah agar tidak banyak dikenakan pembayaran pajak. Begitu juga untuk kepentingan pemilik, laba yang dilaporkan tinggi agar pihak manajemen dapat memperoleh bonus dan komisi besar di akhir tahun.

Disisi lain, pihak manajemen perusahaan mengetahui seluruh informasi dan informasi ini sering kali tidak disampaikan pada pemilik atau investor perusahaan. Pihak manajemen perusahaan terkadang berusaha membuat keputusan dan kebijakan perusahaan dalam rangka memaksimalkan keuntungan dan kepentingannya, yang terkadang mengabaikan kepentingan pemilik dan investor. Merasa kepentingan pemilik dan investor terabaikan, maka pihak inipun berusaha untuk melakukan pengawasan, dimana aktivitas ini membutuhkan biaya tinggi dan akibatnya akan mempengaruhi laba perusahaan. Bila laba turun maka akan mempengaruhi komisi dan bonus pihak manajemen perusahaan. Hal inilah yang menimbulkan konflik kepentingan antara manjamen dan pemilik dan investor perusahaan.

Konflik yang terjadi antara pihak manajemen dan pemilik/ investor perusahaan akan dapat diminimalisir bila perusahaan menerapkan tata kelola (corporate goverment) yang baik. Informasi yang dikuasai oleh satu pihak dapat dikelola dan diketahui oleh berbagai pihak yang berkepentingan. Diyakini bahwa salah satu penyebab krisis keuangan yang terjadi di negara-negara Asia disebabkan oleh lemahnya corporate governance. Cirinya adalah adanya tindakan mementingkan diri 
sendiri di pihak para manajer perusahaan dan mengabaikan kepentingan investor. Hal ini akan berakibat pada jatuhnya harapan para investor atas pengembalian (return) investasi yang telah ditanamkannya. Akibat selanjutnya adalah menurunnya harga-harga saham sehingga pasar modal menjadi tidak berkembang dan menurunnya nilai pertukaran mata uang.

Diyakini bahwa penerapan corporate governance merupakan salah satu faktor yang mampu membangun dan mewujudkan pasar modal yang sehat. Perusahaan yang telah menerapkan corporate governance yang baik akan mendapat penghargaan pada nilai saham atau premium sebesar 20\% - 30\% (Rahayu, 2006). Negara yang memiliki pasar modal yang besar akan memiliki pertumbuhan ekonomi yang lebih cepat di masa datang.

Tata kelola (Corporate Governance) berperan penting dalam mengimplementasikan konservatisma akuntansi. Tata kelola akan menghasilkan monitoring manajemen lebih baik. Prinsip Corporate governance yaitu transparansi dan akuntabilitas juga diterapkan dalam saham berbasis syariah di Indonesia. PT. Bursa Efek Indonesia bekerja sama dengan PT. Danareksa Investment Management (DIM) dalam rangka mengembangkan pasar modal syariah, meluncurkan indeks saham yang dibuat berdasarkan syariah Islam yaitu Jakarta Islamic Indexs (JII). Tujuan pembentukan Jakarta Islamic Indexs (JII) adalah untuk mengukur kinerja suatu investasi pada saham dengan basis syariah sehingga diharapkan dapat meningkatkan kepercayaan investor guna mengembangkan investasi dalam ekuiti syariah.

Penelitian ini untuk mengevaluasi pengimplementasian Corporate Governance pada perusahaan yang terdaftar Jakarta Islamic Indexs (JII). Lara et.al. (2007, 2009) dan Xiang dan Zhu (2009) menyatakan bahwa perusahaan yang memiliki Corporate Governance yang kuat adalah lebih konservatif. Meskipun Corporate Governance memiliki dampak positif pada perusahaan yang menerapkannya, namun untuk kondisi di Indonesia, banyak perusahaan manufaktur yang enggan dievaluasi Corporate Governance karena merasakan tidak ada dampak langsung terhadap harga sahamnya (Rahmi, 2010)

Berdasarkan uraian diatas maka penelitian ini bertujuan untuk menguji "Pengaruh Corporate Governance terhadap Konservatisma akuntansi pada perusahaan yang terdaftar di Jakarta Islamic Indeks."

\subsection{Rumusan Masalah}

Berdasarkan uraian latar belakang diatas, maka permasalahan penelitian ini adalah: "Apakah Corporate Governance berpengaruh positif terhadap konservatisma akuntansi pada perusahaan yang terdaftar di Jakarta Islamic Indeks?

\subsection{Tujuan Penelitian}

Berdasarkan permasalahan diatas maka tujuan penelitian ini adalah untuk: menguji pengaruh Corporate Governance terhadap konservatisma akuntansi pada perusahaan yang terdaftar di Jakarta Islamic Indeks.

\subsection{Manfaat Penelitian}

Penelitian ini diharapkan dapat berguna bagi pihak yang berkepentingan diantaranya kalangan akademisi dan praktisi baik secara empiris dan teoritis.

\section{Tinjauan Kepustakaan}

\subsection{Teori Keagenan (Agency Theory)}

Wolk et. al. (2008, p. 90) menyatakan teori keagenan merupakan teori yang memprediksi dan menjelaskan perilaku pihak-pihak yang terlibat dalam sebuah perusahaan modern dengan pemisahan kepentingan antara kepentingan manajemen dengan kepentingan pemilik perusahaan (ownership). 


\subsection{Teori Sinyal (Signaling Theory)}

Menurut Wolk et. al. (2008, p. 91), teori sinyal menjelas kenapa perusahaan memiliki dorongan untuk melaporkan laporan keuangan secara sukarela (voluntary) kepada pasar modal. Dorongan pertimbangan ekonomilah yang menjadi alasan utama perusahaan membuat laporan keuangan secara sukarela meskipun perusahaan memiliki laporan kinerja yang jelek (bad news). Perusahaan yang mengimplementasikan akuntansi conservatism akan memberikan sinyal adanya perlindungan kepada pihak yang meminjamkan (lender) dan meningkatkan nilai perusahaan.

\subsection{Konservatisma Akuntansi (Accounting Conservatism)}

Conservatism merupakan suatu tindakan berhati-hati terhadap ketidakpastian (uncertainty) dan resiko dalam bisnis (FASB, 1980, para. 95). Wolk et al. (2008: 126- 127) mendefinisikan konservatisma akuntansi sebagai usaha memilih metoda akuntansi berterima umum: (1) memperlambat pengakuan pendapatan (revenue), (2) mempercepat pengakuan pengeluaran (expenses), (3) merendahkan penilaian asset, dan (4) meninggikan penilaian utang.

\subsection{Corporate Governance}

Corporate Governance didefinisikan oleh Shleifer and Vishny (1997) dari perspektif keuangan, sebagai suatu cara perusahan agar investasi para penyandang dana dapat dikembalikan. Warsono et. al. (2009, p.5) mendefinisikan Corporate Governance sebagai sistem yang terdiri dari fungsi-fungsi yang dijalankan oleh pihakpihak yang berkepentingan untuk memaksimalkan penciptaan nilai perusahaan sebagai entitas ekonomi maupun entitas sosial melalui penerapan prinsip-prinsip dasar yang berterima umum.

\section{Metode Penelitian}

Populasi penelitian adalah perusahaan yang terdaftar di Jakarta Islamic Indexs(JII) dari tahun 2008-2012. Sampel dipilih dengan metoda purposive sampling, dengan kriteria sebagai berikut:

1. Perusahaan yang terdaftar di Jakarta Islamic Indexs(JII).

2. Bukan lembaga keuangan maupun perbankan. Hal ini untuk mengantisipasi adanya perbedaan peraturan tertentu yang dapat mempengaruhi variabel dalam penelitian.

3. Perusahaan memiliki data yang dibutuhkan untuk penelitian pada laporan keuangan dari tahun 2008-2012.

Penelitian ini mengunakan data sekunder. Sumber data diperoleh dari: Database Bursa Efek Indonesia yang tersedia di www.idx.co.id. Item-item data yang digunakan dalam penelitian ini yaitu:

1. Data untuk menentukan nilai konservatisma akuntansi meliputi: piutang dagang, asset tetap bruto, total asset, utang dagang, utang lancar meliputi: utang ppn, utang hadiah, utang komisi, utang kontijensi, biaya belum dibayar, penjualan bersih, biaya depresiasi dan amortisasi, kos barang dijual, biaya penjualan, biaya usaha, laba sebelum pajak penghasilan, dan laba kena pajak penghasilan.

2. Data untuk menentukan kualitas Corporate Governance meliputi: jumlah dewan komisaris, persentase komisaris independen, latar belakang pendidikan (kompetensi) dewan komisaris independen.

Konservatisma akuntansi diukur dengan model Lo (2005) yaitu pengukuran alternatif konservatisma. Penghitungan index CG adalah dengan memasukan seluruh komponen. Angka indek tertinggi dalam penelitian ini adalah 3 dan terendah adalah 0 .

Sebelum melakukan pengujian hipotesis dilakukan penentuan nilai-nilai dari 
conservatism accounting dan Corporate Governance sesuai dengan proksi yang telah ditentukan. Hipotesis akan diuji dengan analisis regresi linier sebagai berikut:

$\mathrm{VIKV}=\mathrm{a}_{1}+\mathrm{b}_{1} \mathrm{CG}+\mathrm{e}$.

Keterangan:

VIKV = Konservatisma akuntansi

$\mathrm{CG}=$ Mekanisme CG.

\section{Analisis Hasil dan Pembahasan}

\subsection{Hasil Pengujian Hipotesis}

Penelitian ini untuk menjawab pertanyaan apakah corporate governance berpengaruh terhadap konservatisma akuntansi pada perusahaan yang terdaftar di Bursa Efek Indonesia. Oleh karena itu penelitian ini melakukan pengujian goodness of fit, uji-F, dan uji-t.

Berdasarkan pengujian goodness of fit di tabel 4, Corporate Governance memiliki koefisien determinasi sebesar 0,076. Artinya, variabel independen dalam model regresi dapat menjelaskan variasi variabel dependen sebesar 7,6 \%, sementara itu 92,4\% dijelaskan oleh faktor-faktor lain.

Dari tabel 5 diperoleh nilai $\mathrm{F}$ untuk Corporate Governance sebesar 34,057 dan signifikan, sudah kuat memprediksi variabel dependen konservatisma akuntansi.

Berdasarkan tabel 6 diketahui persamaan regresi linier, sebagai berikut:

$\mathrm{KONSV}=0,963+0,052 \mathrm{CG}$.

Keterangan:

$\begin{array}{ll}\text { Konsv } & =\text { konservatisma akuntansi } \\ \mathrm{CG} & =\text { Corporate Governance }\end{array}$

\section{Analisis Pengaruh Corporate Governance terhadap Konservatisma Akuntansi}

Penelitian ini memprediksi bahwa variabel Corporate Governance berpengaruh positif terhadap Konservatisma Akuntansi. Pada hasil pengujian regresi linier, CG berpengaruh positif $(\mathrm{t}=5,836$, sig $=000)$ signifikan terhadap konservatisma akuntansi. Artinya perusahaan yang dikelola dengan baik maka akan semakin konservatif. Salah satu prinsip corporate governance adalah transparansi. Sebagai contoh bila perusahaan transparan atas informasi kepada publik, ini menunjukan bahwa perusahaan akan menyampaikan informasi secara hati-hati atau konservatif atas semua informasi agar tidak menimbulkan berbagai penafsiran yang mungkin bisa menyesatkan, dan akan mempengaruhi penilaian publik atas perusahaan tersebut.

Selanjutnya pada hasil penelitian sebelumnya menyatakan bahwa perusahaan menjadi sorotan publik (masyarakat dan pemerintah) karena itu menyelenggarakan tata kelola yang baik melalui metode akuntansi konservatif. Semakin baik corporate governance suatu perusahaan, semakin konservatif (Lara et. al. (2007, 2009) Xiang Zhu (2009)). Hal ini ditunjukkan pada fungsi persamaan $\mathrm{KONSV}=0,963+0,052$ $\mathrm{CG}$, dimana bila perusahaan memperoleh skor $\mathrm{CG}=0$, maka nilai konservatisma akuntansi adalah 0,963. Bila skor CG perusahaan adalah 1, maka nilai konservatisma akuntansi adalah 1,015. Bila CG dinilai 2, maka konservatisma akuntansi adalah 1,067. Jika perusahaan berapa pada skor CG tertinggi yaitu 3 maka nilai konservatisma akuntansinya adalah 1,119. Mengacu pada perolehan skor CG dan nilai konservatisma akuntansi tersebut maka dapatlah dikatakan bahwa penelitian ini konsisten dengan penelitian sebelumnya bahwa semakin tinggi corporate governance maka akan semakin konservatif. Oleh karena itu perusahaan yang listing di Bursa Efek Indonesia dapat memenuhi kondisi tersebut.

Kemudian berdasarkan hasil penelitian diperoleh nilai adjusted $R$ Square sebesar 7,6\%. Artinya, $\mathrm{CG}$ hanya berpengaruh sebesar $7,6 \%$ terhadap konservatisma akuntansi, sementara 92,4\% dijelaskan oleh faktor-faktor lain seperti size, leverage. Ini memberi sinyal bahwa CG belum berperan optimal pada perusahaan yang listing di BEI, 
meskipun perusahaan yang dengan peringkat CG tertinggi menunjukan semakin konservatif. Disisi lain keputusan investasi para investor belum sepenuhnya melihat pada kualitas CG suatu perusahaan, tetapi masih berpedoman pada laporan keuangan yang menunjukan berapa keuntungan yang bisa diperoleh bila berinvestasi. Padahal sebagaimana diketahui bahwa perusahaan yang dikelola dengan baik arti kata memiliki tingkat CG yang tinggi akan lebih menjanjikan secara ekonomis yaitu nilai sahamnya naik sebesar 20\% - 30\% (Rahayu, 2006) dan pengaruhnya akan dinikmati dalam jangka panjang.

Melihat pada hasil penelitian ini, dapat dikatakan bahwa CG kurang berperan pada perusahaan manufaktur yang listing di Bursa Efek Indonesia. Oleh karena itulah, banyak perusahaan tersebut merasa enggan untuk dievaluasi efektivitas CG-nya oleh The Indonesian Institute for Corporate Governance (IICG).

\section{Penutup}

\subsection{Kesimpulan}

Penelitian ini bertujuan menguji pengaruh Corporate Governance terhadap konservatisma akuntansi. Penelitian ini dilakukan pada perusahaan manufaktur yang terdaftar di BEI dari tahun 2005 - 2010, karena perusahaan tersebut merupakan perusahaan yang terbanyak listing di BEI dan memiliki keengganan untuk mengikuti evaluasi dari penerapan Corporate Governance yang dilaksanakan oleh lembaga The Indonesian Institute for Corporate Governance (IICG). Metoda analisis data yang digunakan yaitu regresi linier. Sebelum melakukan pengujian hipotesis, terlebih dahulu dilaksanakan pengujian asumsi klasik yakni uji normalitas residual, uji multikolinearitas, uji heterokedastisitas, dan uji autokorelasi. Penelitian ini dapat memenuhi uji asumsi klasik yang menghasilkan Best Linear Unbiased Estimator (BLUE).

Berdasarkan pada hasil penelitian maka untuk hipotesis 1 terdukung, karena hasil dan prediksian adalah sama secara statistik signifikan. Hasil menyatakan bahwa corporate governance mempengaruhi secara positive dan signifikan terhadap konservatisma akuntansi. Oleh sebab itu dapat disimpulkan bahwa Corporate Governance yang merupakan variabel independen dapat mempengaruhi konservatisma akuntansi. Mengacu pada hasil adjusted $R$ square sebesar 7,6\% dapat dinyatakan bahwa besarnya pengaruh Corporate Governance hanya sebesar 7,6\% terhadap konservatisma akuntansi, sementara 92,4\% dijelaskan oleh faktor-faktor lain. Ini memberi sinyal bahwa CG kurang berperan dalam keputusan investasi para investor meskipun perusahaan yang memiliki kualitas CG tinggi akan semakin konservatif. Oleh karena itulah banyak perusahaan manufaktur yang merasa enggan untuk dievaluasi kualitas CG nya.

\subsection{Rekomendasi}

Berdasarkan pada hasil penelitian ini, ada beberapa hal yang disarankan yaitu: (1) agar para akademisi yang tertarik meneliti konservatisma akuntansi dan Corporate Governance untuk menambah jumlah sampel penelitian pada berbagai sektor industri supaya dapat digeneralisasikan. (2) Menggunakan rentang waktu yang lebih panjang. (3) Menggunakan instrument Corporate Governance yang lebih banyak guna menghasilkan penelitian yang lebih valid.

\section{Daftar Pustaka}

Lara, Juan Manuel G., Beatriz G. Osma, Fernando Penalva. 2009. Accounting Conservatism And Corporate Governance. Springer Science And 
Business Media . Rev Account Stud. Vol. 14, pp. 161-201.

Lara, Juan Manuel Garci'A, Beatriz Garci'A Osma and Fernando Penalva. 2007. Board Of Directors' Characteristics And Conditional Accounting Conservatism: Spanish Evidence. European Accounting Review. Vol. 16, No. 4, pp. 727-755.

Lo, Eko. W. 2005. Pengaruh Tingkat Kesulitan Keuangan Perusahaan Terhadap Konservatisma Akuntansi. Simposium Nasional Akuntansi VIII, pp. 396-440.

Rahayu, Eva Martha. 2006. GCG, Mudah Tapi Masih Diemohi. SWA 26/XII/1120 Desember, pp. 36-46.

Rahmi, Febri. 2010. Pengaruh Corporate

Governance terhadap Konservatisma akuntansi pada Perusahaan yang Terdaftar di Bursa Efek Indonesia.

Shleifer, Andrei and Robert W. Vishny. 1997. A Survey of Corporate Governance. The Journal of Finance. Vol. 12 (2), pp. 737-782.

Warsono, Sony, Fitria Amalia, dan Dian Kartika Rahajeng. 2009. Corporate Governance Concept And Model, Preserving True Organization Welfare. Center Good Corporate Governance FEB UGM. Yogyakarta.

Wolk, Harry I, James L. Dodd, John J. Rozycki. 2008. Accounting Theory, Conceptual Issues in a Political and Economic Environment. Sevent Edition. Sage Publication, Inc.

Xia, Donglin and Song Zhu. 2009. Corporate Governance and Accounting Conservatism in China. China Journal of Accounting Research. Vol. 2, pp. 81108

\section{Lampiran :}

Hasil Uji Goodness of fit

\begin{tabular}{|l|l|l|l|l|}
\hline Model & $\mathrm{R}$ & R Square & $\begin{array}{l}\text { Adjusted R } \\
\text { Square }\end{array}$ & $\begin{array}{l}\text { Std. Error of the } \\
\text { estimate }\end{array}$ \\
\hline CG & 0,280 & 0,078 & 0,076 & 0,1747 \\
\hline
\end{tabular}

Sumber: laporan keuangan yang diolah

Hasil uji statistik F

\begin{tabular}{|l|l|l|l|l|l|}
\hline Model & & Sum of square & df & F & Sig \\
\hline 2. CG & Regresion & 1,040 & 1 & 34,057 & 0,000 \\
\hline & Residual & 12,246 & 401 & & \\
\hline & Total & 13,286 & 402 & & \\
\hline
\end{tabular}

Sumber: laporan keuangan yang diolah.

Hasil uji statistik t

Coofficients

\begin{tabular}{|l|l|l|l|l|}
\hline Model & \multicolumn{4}{l|}{ Unstandardized Coefficients } \\
\hline & B & Std. Error & t & sig \\
\hline Constant & 0,963 & 0,012 & 81,985 & 0,000 \\
\hline CG & 0,052 & 0,009 & 5,836 & 0,000 \\
\hline
\end{tabular}

Sumber: laporan keuangan yang diolah 